\title{
Jakub Siotor
}

\section{Ukraina a tranzyt rosyjskiego gazu do Unii Europejskiej. Stan obecny oraz perspektywy na przyszłość}

\section{Wprowadzenie}

Strategiczne znaczenie surowców energetycznych sprawia, że każde państwo, każda organizacja czy jednostka wykazuje na nie stosowne zapotrzebowanie. Nierównomierne geograficzne rozmieszczenie surowców na Ziemi decyduje o tworzącej się zależności konsumentów od producentów. Często też po drodze znajdują się pośrednicy, którzy w międzynarodowym obrocie surowcami przyjmują formę państw tranzytowych. Z punktu widzenia bezpieczeństwa energetycznego, państwo które nie jest samowystarczalne energetycznie, powinno zabezpieczyć dostawy surowców z zagranicy. Nie może to się odbyć bez odpowiedniego kontraktu z eksporterem, ale równie ważna jest kwestia uregulowania warunków przesyłu z krajami tranzytowymi.

Ukraina to obecnie jedno z największych i najważniejszych państw tranzytowych rosyjskiego gazu do Unii Europejskiej. Jest to z jednej strony wynik położenia geograficznego na styku Europy Wschodniej i Zachodniej, a z drugiej strony wynik zaszłości historycznych. Jeszcze za czasów istnienia ZSRR, to właśnie przez ukraińską republikę związkową płynęło najwięcej gazu do Europy Zachodniej'. Wiązało się to $\mathrm{z}$ intensywną rozbudową infrastruktury przesyłowej na terenie całego kraju. W skład ukraińskiego systemu przesyłowego wchodzi obecnie 37,5 tys. km gazociągów oraz 13 dużych podziemnych magazynów o łącznej kubaturze $30 \mathrm{mld} \mathrm{m}^{32}$. Potencjał przesyłowy ukraińskiego systemu gazociągów wynosi natomiast $140 \mathrm{mld}^{3}$. Na początku XXI w. przez Ukrainę płynęło $110 \mathrm{mld} \mathrm{m}^{3}$ błękitnego paliwa, co stanowiło 80\% dostaw do UE. W $2017 \mathrm{r}$.

Ł. Wojcieszak, Polska, Ukraina i Białoruś wobec problemu dostaw i tranzytu rosyjskiego gazu, Bielsko-Biała 2013, s. 289-291.

2 Są to obecnie największe podziemne magazyny gazu w Europie. 
z kierunku ukraińskiego do UE dotarło ponad $90 \mathrm{mld} \mathrm{m}^{3}$ gazu, co stanowiło ok. 50\% dostaw rosyjskiego surowca do Wspólnoty ${ }^{3}$.

\section{Obecny model ukraińsko-rosyjskiej współpracy gazowej}

Niewątpliwym atutem Ukrainy w powyższej kwestii jest właśnie odziedziczona po ZSRR rozbudowana sieć systemu przesyłowego gazu ziemnego. Tworzy to pewnego rodzaju współzależność producenta (Rosji) i kraju tranzytowego (Ukrainy). Rosja chcąc sprzedać odpowiednią ilość surowca do Europy Zachodniej właściwie nie miała innej alternatywy jak tranzyt przez Ukrainę. W roku 1999 co prawda uruchomiony został gazociąg Jamalski biegnący przez Białoruś i Polskę do Niemiec, jednak jego przepustowość nie wystarczała na zaspokojenie potrzeb klientów w Europie Zachodniej. Z drugiej strony jednak, Ukraina była niemalże całkowicie uzależniona od dostaw gazu ze wschodu. Na przełomie XX i XXI w. roczne zużycie gazu na Ukrainie oscylowało w okolicach $100 \mathrm{mld} \mathrm{m}^{3}$ (z czego ok. $80 \%$ pochodziło z Rosji), co plasowało Ukrainę wśród jednych z największych konsumentów gazu w Europie ogółem oraz per capita ${ }^{4}$. Był to wynik kilku czynników: bardzo niskiej ceny rosyjskiego surowca, wysokiej energochłonność gospodarki, a także przestarzałej i nieefektywnej infrastruktury5 ${ }^{5}$. Do 2004 r. Ukraina płaciła jedną z najniższych stawek za gaz w Europie - 50 USD za $1000 \mathrm{~m}^{3}$, podczas gdy np. Niemcy płaciły wtedy ok. $200 \mathrm{USD}^{6}$. Mimo niskiej ceny, efektem powyższej sytuacji było duże zadłużenie ukraińskiego Nafothazu (ukraiński operator przesyłu gazu) wobec Gazpromu, co właściwie niwelowało wszelkie korzyści Ukrainy z tranzytu gazu na Zachód ${ }^{7}$.

Sytuacja zaczęła systematycznie ulegać zmianie po 2004 r., a więc po „Pomarańczowej rewolucji”, którą można określić jako swoistą cezurę w relacjach energetycznych Rosja - Ukraina. Dotychczas uzależniona od rosyjskich dostaw gazu Ukraina często ulegała naciskom politycznym Rosji, pozostając całkowicie w jej strefie wpływów. W 2004 r. do władzy doszedł Wiktor Juszczenko, kojarzony, jako prozachodni polityk, niechętny wobec Kremla. Jednym z głównych problemów,

3 E. Paszkiewicz, Bezpieczeństwo energetyczne Unii Europejskiej w sektorze gazu ziemnego, „Przegląd Geopolityczny” 2018, nr 23, s. 123-143.

4 G. Gromadzki, W. Konończuk, Energetyczna gra. Ukraina, Mołdawia i Białoruś między Unia $z$ Rosja, Warszawa 2007, s. 13-14

Ł. Wojcieszak, op.cit., s. 292

6 Cena porównywalna jedynie z ceną dla Białorusi. Był to jeden z czynników uzależniania republik postsowieckich od rosyjskiego surowca. Zob. A. Szeptycki, Relations between Russia and Ukraine in the gas sector, [w:] Geopolitics of pipelines. Energy interdependance and inter-state relations in the post-soviet area, red. E. Wyciszkiewicz, Warsaw 2009, s. 93.

7 M. Ruszel, Wpływ rosyjsko-ukraińskich kryzysów gazowych na politykę energetyczną UE - ujęcie teoretyczne, Rzeszów 2015. 
jakimi nowa władza chciała się zająć, było uregulowanie długu gazowego, a także podniesienie ceny za tranzyt rosyjskiego surowca. W związku z powyższym już w 2005 r. Gazprom postanowił renegocjować zawartą pod koniec XX w. umowę, w wyniku czego cena gazu dla Ukrainy miała wzrosnąć z 50 do ok. 230 USD $\mathrm{za} \mathrm{m}^{38}$. Strona ukraińska nie wyrażała na to zgody i sytuacja ta pociągnęła za sobą szereg innych wydarzeń, które w późniejszym czasie przyjęły nazwę „rosyjsko-ukraińskich kryzysów gazowych".

Zwycięstwo obozu „Pomarańczowej rewolucji” na Ukrainie oraz postępująca świadomość Rosji o uzależnieniu od tranzytu gazu przez Ukrainę, dały początek tworzeniu się koncepcji budowy instalacji przesyłowych z pominięciem lub ograniczeniem roli krajów tranzytowych, o czym szerzej wspomnę w dalszej części opracowania. W tym miejscu należy poruszyć natomiast problem zaopatrzenia Ukrainy w gaz na potrzeby wewnętrzne. Tak jak wyżej wspomniałem, jeszcze na początku XXI w. Ukraina była jednym z największych konsumentów gazu w Europie. W ostatnich latach zużycie gazu jednak znacząco spadło, ze wspomnianych $100 \mathrm{mld} \mathrm{m}^{3}$ rocznie na początku XXI w. do ok. $32 \mathrm{mld} \mathrm{m}^{3} \mathrm{w} 2017$ r. Powody tego są następujące:

- aneksja Krymu przez Rosję oraz konflikt w Donbasie doprowadziły do pogłębienia się kryzysu gospodarczego i częściowej deindustrializacji, co poskutkowało ograniczeniem zużycia gazu;

- państwo ukraińskie utraciło kontrolę nad energochłonnym przemysłem w Donbasie;

- modernizacja linii przesyłowych, która z jednej strony ogranicza utratę gazu w transporcie, ale też przekłada się na wyższą cenę dla odbiorcy, a tym samym mniejsze zużycie;

- znacznie wyższa cena importowanego surowca9

Spadek zużycia gazu przyczynił się w pewnym stopniu do zwiększenia bezpieczeństwa energetycznego kraju. W 2017 r. import gazu do Ukrainy stanowił tylko $35 \%$ zużywanego surowca (ok. $12 \mathrm{mld} \mathrm{m}$ ), podczas gdy 10 lat wcześniej było to aż $80 \%$. Bieżące zapotrzebowanie jest w dużym stopniu uzupełniane przez systematycznie rosnące od kilku lat wydobycie krajowe. Obecnie jest ono na poziomie ok. 20 mld $\mathrm{m}^{3}$ rocznie, a ukraińska spółka wydobywcza UkrGasVydobuvannya zmodernizowała ostatnio w tym celu 744 odwierty oraz rozpoczęła eksploatację 69 nowych $^{10}$. Warto jednak wskazać, że potencjał wydobywczy Ukrainy jest dużo wyższy. Według Międzynarodowej Agencji Energetycznej zasoby gazu

A. Szeptycki, op.cit., s. 104.

M. Zaniewicz, Ukraina może przetrwać ponad rok bez importu gazu. Czy później kupi go od Polski?, https://www.energetyka24.com/ukraina-moze-przetrwac-ponad-rok-bez-importugazu-a-potem-kupowac-go-od-polski-analiza (15 IV 2019).

10 M. Kozak, Ukraina na drodze do niezależności gazowej, https://www.obserwatorfinansowy.pl/ forma/rotator/ukraina-na-drodze-do-niezaleznosci-gazowej/ (15 X 2019). 
ziemnego Ukrainy są szacowane na 1 bln $\mathrm{m}^{3}$, co plasuje ten kraj na 3 miejscu w Europie. W wyniku rosyjsko-ukraińskiego konfliktu obecnie niemalże całość rosyjskiego gazu płynącego przez Ukrainę jest wysyłana na zachód i południe Europy. W 2017 r. było to $93 \mathrm{mld} \mathrm{m}^{3}$, z czego ponad 90 mld trafiło do UE (wykres nr 1) ${ }^{11}$. Pozwoliło to Ukrainie w 2017 r. zwiększyć zyski z tranzytu gazu do 700 mln USD ${ }^{12}$. Ponadto w 2018 r. zakończył się trwający od 2014 r. ukraińsko-rosyjski spór prowadzony przed Trybunałem Arbitrażowym w Szwecji. Trybunał przyznał odszkodowanie na rzecz Ukrainy w wyniku niedostarczania przez Gazprom odpowiedniej ilości gazu w latach wcześniejszych ${ }^{13}$. Ówczesna umowa na bieżący tranzyt rosyjskiego surowca obowiązywała jednak tylko do 31 XII 2019 r.

Wykres 1. Przesył rosyjskiego gazu przez Ukrainę do Europy w latach 2011-2017 (w mld $\mathrm{m}^{3}$ )

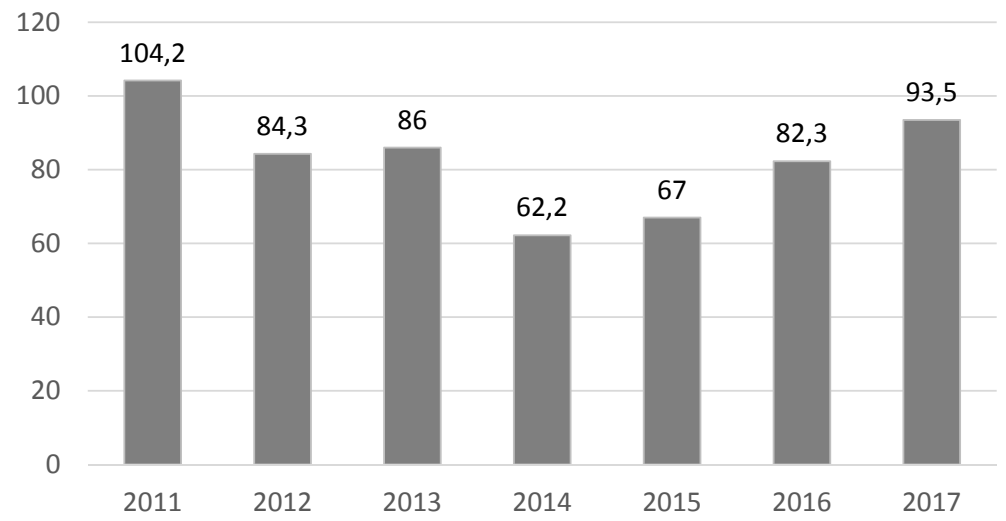

Źródło: opracowanie własne na podstawie „Nafothaz Annual Report 2017”.

Do momentu wystąpienia konfliktu ze stroną rosyjską, inwestycje w przemysł gazowy nie cieszyły się dużym zainteresowaniem (surowiec był bardzo tani). Obecnie zaś jest to konieczność dla gospodarki ukraińskiej. Mimo zwiększającego się wydobycia krajowego, wciąż ponad 1/3 zapotrzebowania na gaz musi

11 Nord Stream 2 i Ukraina: Bitwa o tranzyt, https://www.energetyka24.com/nord-stream-2-i-ukraina-bitwa-o-tranzyt-raport (22 IV 2019).

12 Import obecnie pochodzi z krajów UE w postaci rewersu zwrotnego gazu rosyjskiego.

13 Podobne rozstrzygnięcie w sporze z Gazpromem przed Trybunałem Arbitrażowym uzyskało PGNiG w marcu 2020 r., choć tym razem chodziło bezpośrednio o zawyżaną przez Rosjan cenę surowca. Zob. W. Jakóbik, PGNiG wygrał z Gazpromem. Rosjanie będa musieli zwrócić ok. 1,5 mld dolarów, https://biznesalert.pl/pgnig-wygral-z-gazpromem-rosjanie-bedamusieli-zwrocic-ok-15-mld-dolarow/ (2 IV 2020). 
pochodzić z innych źródeł. W tym celu od dłuższego czasu magazynowane są nadwyżki surowca, które w 2017 r. sięgnęły rekordowego poziomu $17 \mathrm{mld} \mathrm{m}$, co pozwala przetrwać Ukrainie ponad rok bez ewentualnego importu ${ }^{14}$. Oprócz gromadzenia zapasów surowca władze w Kijowie rozwijają sieć połączeń międzysystemowych z państwami UE, w tym z Polską. Umożliwia to odbieranie gazu w postaci rewersu zwrotnego nadwyżek gazu rosyjskiego przesyłanego do Polski lub Niemiec, ale też na odbiór gazu pochodzącego z innych kierunków jak chociażby z terminala LNG w Świnoujściu.

Dziś już wiemy, że wspomniana wyżej umowa na przesył rosyjskiego gazu przez Ukrainę została przedłużona. Obecny kontrakt obowiązuje do $2025 \mathrm{r}$. i opiewa na sumę 7 mld USD ${ }^{15}$. Jednak jeszcze pod koniec zeszłego roku nie było to takie oczywiste, a strona ukraińska obawiała się wstrzymania tranzytu w przypadku braku porozumienia. Biorąc pod uwagę trwające napięcie na linii Moskwa - Kijów, a także rosnące koszty przesyłu dla strony rosyjskiej, należy zadać pytanie czy Ukrainie rzeczywiście groziła lub grozi w przyszłości utrata statusu państwa tranzytowego? Aby znaleźć odpowiedź na to pytanie, w pierwszej kolejności należy rzucić nieco światła na zależność występującą między UE a Rosją w kontekście dostaw rosyjskiego gazu. W 2015 r. Rosja sprzedała na zachód i południe Europy ok. $190 \mathrm{mld} \mathrm{m}^{3}$ gazu, co stanowiło ok. 80\% eksportu rosyjskiego surowca ${ }^{16}$. Wiele państw UE w dużym stopniu jest uzależniona od tych dostaw, jednak podobnie Rosja jest uzależniona od europejskiego rynku zbytu. W obrocie towarami paliwowo-energetycznymi UE odpowiada za ok. $60 \%$ dochodów rosyjskiego eksportu i, mimo prognoz, że stosunek ten będzie malał, to w perspektywie najbliższych lat wciąż pozostanie na bardzo wysokim poziomie ${ }^{17}$.

\section{Rosyjskie próby ominięcia Ukrainy}

We wcześniejszej części opracowania wskazano, że ok. 50\% rosyjskiego gazu trafia obecnie do UE przez Ukrainę. Pozycja naszego wschodniego sąsiada wydaje się więc niezagrożona. W tym miejscu należy jednak powrócić do szerszego omówienia koncepcji budowy przez Gazprom instalacji przesyłowych z pominięciem państw tranzytowych. Poniżej zaprezentowane są najważniejsze inwestycje.

14 M. Zaniewicz, op.cit.

15 Gazprom i Ukraina podpisały kontrakt na tranzyt gazu, https://www.energetyka24.com/ gazprom-i-ukraina-podpisaly-kontrakt-na-tranzyt-gazu (16 IV 2020).

16 P. Turowski, Bezpieczeństwo energetyczne na szczycie NATO w Warszawie: priorytetem dywersyfikacja dostaw ropy i gazu, [w:] Bezpieczeństwo energetyczne. Koncepcje, wyzwania, interesy, red. J. Gryz, A. Podraza, M. Ruszel, Warszawa 2018, s. 105-110.

17 K. M. Pronińska, Bezpieczeństwo energetyczne w stosunkach UE - Rosja. Geopolityka i Ekonomia surowców energetycznych, Warszawa 2012, s. 230. 
Jednym z najbardziej znanych przykładów jest biegnący po dnie Morza Bałtyckiego gazociąg północny Nord Stream, bezpośrednio łączący Rosję (Wyborg) i Niemcy (Greifswald). Projekt jego budowy powstał na początku XXI w., co było spowodowane $\mathrm{z}$ jednej strony rosnącym zapotrzebowaniem na surowiec w Europie Zachodniej, a z drugiej coraz częściej pojawiającymi się problemami w tranzycie przez Ukrainę i Białoruś. Udziałowcami są: rosyjski Gazprom (51\%), niemieckie firmy E.ON i Wintershal (po 20\%) oraz holenderska firma Gasunie (9\%). Pierwsza nitka gazociągu została uruchomiana w 2011 r., a rok później druga. Łączna przepustowość obydwu nitek wynosi $55 \mathrm{mld} \mathrm{m}^{3}$ rocznie $^{18}$.

Kilka lat po realizacji Nord Stream pojawił się kolejny projekt, dotyczący budowy równoległego gazociągu pod nazwą Nord Stream 2. Udziałowcami są: Gazprom, holenderski Shell, niemicki OMV, Wintershall i Uniper oraz francuski Engie $^{19}$. Przepustowość gazociągu ma być analogiczna do pierwszej inwestycji Nord Stream, a więc $55 \mathrm{mld} \mathrm{m}^{3}$. Inwestycja jest obecnie w trakcie realizacji, rozpoczęła się w lecie 2018 r. i jej zakończenie planowane było na koniec 2019 r. Już dziś wiemy, że inwestycja nie została ukończona na czas. Jedną z przyczyn takiej sytuacji była niewątpliwie decyzja USA o objeciu projektu sankcjami ${ }^{20}$.

Dwa powyższe gazociągi biegną po dnie Morza Bałtyckiego, jednak Rosjanie planowali rozpoczęcie budowy gazociągu łączącego Rosję z Bułgarią pod nazwą South Stream ${ }^{21}$, projekt ten został jednak porzucony. Obecny projekt nosi nazwę Turkish Stream (pol. Turecki Potok) i łączy rosyjskie miasto Anapa z tureckim Kiyikoy, a następnie ma biec dalej przez Grecję i Bałkany do krajów UE. Gazociąg ma mieć docelową przepustowość $31,5 \mathrm{mld} \mathrm{m}^{3}$ (dwie nitki po $15,75 \mathrm{mld} \mathrm{m}^{3}$ ). W listopadzie 2019 r. gazociąg został uruchomiony ${ }^{22}$.

18 Nord Stream, https://www.nord-stream.com/about-us/ (22 IV 2019).

19 Nord Stream 2, https://www.nord-stream2.com/company/shareholder-and-financial-investors/ (10 XI 2020). Zob. także A. Łaskot-Strachota, S. Kardaś, R. Bajczuk, Porozumienie w sprawie finansowania Nord Stream 2, https://www.osw.waw.pl/pl/publikacje/analizy/2017-04-26/ porozumienie-w-sprawie-finansowania-nord-stream-2 (9 XI 2020).

20 W 2017 r. USA przyjęły ustawę, która umożliwiała prezydentowi nałożenie sankcji na Nord Stream 2, co odstraszyło część banków europejskich i amerykańskich od udziału w finansowaniu projektu. Następnie, pod koniec 2019 r., administracja Donalda Trumpa zdecydowała o nałożeniu sankcji na podmioty dostarczające sprzęt do realizacji inwestycji. W wyniku tej decyzji swój udział w projekcie zawiesiła szwajcarska firma Allseas, co było o tyle istotne dla terminowej realizacji, że w przeciwieństwie do Gazpromu posiadała ona już odpowiedni sprzęt i certyfikaty do układania gazociągu w duńskiej wyłącznej strefie ekonomicznej. Zob. M. Strzałkowski, Szwajcarska spółka zawiesza budowę Nord Stream 2, https://www.euractiv.pl/section/energia-i-srodowisko/news/szwajcarska-spolka-zawiesza-budowe-nord-stream-2/ (10 XI 2020).

21 T. Młynarski, Bezpieczeństwo energetyczne w pierwszej dekadzie XXI wieku. Mozaika interesów i Geostrategii, Kraków 2011, s. 174.

22 A. Wróbel, Turecki Potok - gazociag, którym rosyjski gaz trafi na południe Europy, https:// www.portalmorski.pl/porty-logistyka/44195-turecki-potok-gazociag-ktorym-rosyjski-gaztrafi-na-poludnie-europy (12 II 2020). 
Nie trudno zauważyć, że wszystkie powyższe inwestycje są projektowane z pominięciem dotychczasowych krajów tranzytowych (Ukrainy i Białorusi), ale też środkowo-europejskich krajów UE, jak chociażby Polski czy Słowacji, nie wspominając już o krajach bałtyckich. Stąd rodzi się wiele kontrowersji i rozbieżności stanowisk w UE, a pomijane kraje starają się lobbować przeciwko ich realizacji23. Trzeba przyznać, że głos ten nie rozchodzi się bez echa. Nord Stream 2 napotyka kolejne trudności w finalizacji i nie ma pewności, czy gaz popłynie od razu po zakończeniu jego budowy. Problem dla udziałowców stanowi bowiem tzw. Trzeci pakiet energetyczny UE, który zabrania właścicielowi infrastruktury przesyłowej (Gazprom) pełnienia jednocześnie roli dostawcy surowca ${ }^{24}$. Pozostaje też kwestia czysto ekonomiczna, związana z kosztami przesyłu gazu. Gazprom utrzymuje, że całościowe koszty transportu po dnie Morza Bałtyckiego są oczywiście niższe niż drogą lądową. Jednak szef East European Gas Analysis, Michaił Korczemkin stwierdził, że jest na odwrót - w 2014 r. transport $1000 \mathrm{~m}^{3}$ gazu przez Ukrainę kosztował 33 USD, gazociągiem Nord Stream natomiast 44 USD $^{25}$.

W roku 2019 zapotrzebowanie UE na import gazu ziemnego wyniosło $398 \mathrm{mld} \mathrm{m}^{3}$, z czego ok. 41\%, a więc 163 mld $\mathrm{m}^{3}$, surowca pochodziło z Rosji. Głównym szlakiem dostaw była Ukraina, przez terytorium której przepłynęło $74 \mathrm{mld} \mathrm{m}^{3}$ (45\%) rosyjskiego paliwa, $53 \mathrm{mld} \mathrm{m}^{3}$ po dnie Morza Bałtyckiego i reszta przez Białoruś do Polski i Niemiec gazociągiem jamalskim ${ }^{26}$. Biorąc pod uwagę optymistyczny wariant uruchomienia Nord Stream 2 w roku 2020, nie będzie on w stanie uzupełnić zapotrzebowania Wspólnoty na gaz, wyłączając tranzyt przez Ukrainę i Białoruś. Co więcej, IEA szacuje, że zużycie gazu w Europie będzie wzrastać, bardziej więc prawdopodobne, że projektowane gazociągi omijające naszych

23 Słowacki premier Robert Fico dosadnie się wyraził w temacie budowy Nord Stream 2 mówiąc, że Rosja i Niemcy „robią z nas idiotów”, Polska przeciw Nord Stream II. „Prawo UE musi być przestrzegane", https://www.energetyka24.com/polska-przeciw-nord-stream-ii-prawo-uemusi-byc-przestrzegane (30 IV 2019).

24 W przypadku Nord Stream 1 Komisja Europejska ustanowiła wyjątek, gdyż inwestycja powstała przed wprowadzeniem w życie pakietu. TSUE orzekł bowiem, że inwestycje ukończone przed 23 V 2019 r. mogą podlegać zwolnieniu od stosowaniu niektórych zapisów dyrektywy UE dotyczącej wspólnych zasad rynku wewnętrznego gazu ziemnego, co leży w gestii krajowych organów regulacyjnych. Zob. Sąd UE odrzucił skargi Nord Streamu dyrektywe gazowa, https://serwisy.gazetaprawna.pl/energetyka/artykuly/1478089,sad-ue-odrzucilskargi-nord-streamu-na-dyrektywe-gazowa.html (11 XI 2020); W. Jakóbik, Handelsblatt: Niemcy nie zwolniq Nord Stream 2 z prawa unijnego. Dalsze opóźnienie?, https://biznesalert. $\mathrm{pl} /$ handelsblatt-nord-stream-2-nie-bedzie-wylaczenie-niemcy-federalna-agencja-siecibundesnetzagentur-energetyka-gaz/ (1 V 2020).

25 Gazowe porozumienie Niemiec i Rosji uderza w Europę Środkowa, https://www.energetyka24. com/gazowe-porozumienie-niemiec-i-rosji-uderza-w-europe-srodkowa (4 V 2019).

26 European Commission, Quarterly Report on European Gas Markets, Market Observatory for Energy, DG Energy vol. 12, s. 7, https://ec.europa.eu/energy/sites/ener/files/quarterly_report_ on_european_gas_markets_q4_2019_final.pdf (9 XI 2020). 
wschodnich sąsiadów będą uzupełniać rosnące zapotrzebowanie. Należy jednak przypuszczać, że ilość przesyłanego gazu przez Ukrainę będzie spadać i w obecnych warunkach wydaje się niemożliwy powrót do stanu z początku XXI w., kiedy przez Ukrainę płynęło aż $120 \mathrm{mld}^{3}$ rosyjskiego gazu ${ }^{27}$.

\section{Wnioski}

Ukraina w 2020 r. pozostanie państwem tranzytowym rosyjskiego gazu do UE, ilość przesyłanego gazu będzie jednak spadać w kolejnych latach. Biorąc pod uwagę fakt, że obecnie Ukraina nie importuje gazu rosyjskiego na własne potrzeby, zapotrzebowanie to będzie stale uzupełniane $\mathrm{z}$ rosnącego wydobycia krajowego oraz z importu z krajów UE. Nagłe zapotrzebowanie na surowiec będzie uzupełniane z podziemnych magazynów gazu. Rząd ukraiński najprawdopodobniej będzie kontynuował politykę modernizacji sieci przesyłowych oraz promował ograniczanie nadmiernego zużycia gazu przez odbiorców końcowych, co wpłynie na dalszą poprawę efektywności energetycznej. Trzecie, największe w Europie, zasoby gazu ziemnego dają Ukrainie szanse, aby stać się eksporterem surowca w perspektywie kilkunastu kolejnych lat.

Na koniec warto dodać komentarz, że artykuł powstawał głównie na przełomie lat 2019 i 2020, a więc w czasie sprzed wybuchu pandemii COVID-19. Sytuacja epidemiczna na początku 2020 r. na świecie i w Europie sprawiła, że gospodarki wielu krajów zostały zamrożone i sparaliżowane. Może to w najbliższym czasie doprowadzić do spadku zużycia surowców energetycznych w krajach Unii Europejskiej, w tym gazu ziemnego. Dzieje się tak zazwyczaj, gdy mamy do czynienia z kryzysem gospodarczym, który co wielce prawdopodobne nasili się w drugiej połowie 2020 roku. Sytuacja na Ukrainie, jak i w całej Europie może zatem ulec zmianie.

\section{Abstract \\ Jakub Siotor}

\section{Ukraine and Russian gas transit to the European Union. Current situation and perspectives for the future}

Ukraine is the most important transit state of Russian gas to the European Union. The annexation of Crimea in 2014 caused the military conflict what affects mu-

27 https://warsawinstitute.org/gas-transit-ukraine/ (5 V 2019). 
tual business relations between those two countries until today. It was one of the reasons that made Gazprom start thinking of new gas transition installation omitting Ukraine. The purpose of the study is to show current role of the Ukraine in Russian gas transit to the European Union. The first part of the article describes current situation of the gas sector in Ukraine and historical review of relations with Russia concerning gas trade. The second part shows current ways of Russian gas distribution to the EU and the perspectives connected with new gas pipelines projects - Nord Stream 2 and Turkish Stream. The third part focuses on giving an answer to the question: weather the Ukraine still is to be the Russian gas transit state in the second decade of the $21^{\text {st }}$ century? The study is based on scientific and press articles as well as on information given at official websites of the following institutions: European Union, government of Ukraine, government of Russia, NGOs from Ukraine, Russia and EU states. The article is also based on discussion that took place in Warsaw at $11^{\text {th }}$ of May 2019 during International Conference Quo Vadis Ukraine held by phd research organization „Ucrainica”.

Keywords: energy security, Russia-Ukraine gas relations, natural gas pipelines

\section{References}

Bartodziej, G., Tomaszewski, M. Polityka energetyczna i bezpieczeństwo energetyczne, „Nowa Energia” 2009.

Gromadzki, G., Konończuk, K., Energetyczna gra. Ukraina, Mołdawia i Białoruś między Unia z Rosja, Warszawa 2007.

Gazprom i Ukraina podpisaly kontrakt na tranzyt gazu, https://www.energetyka24.com.

Jakóbik, W., Handelsblatt: Niemcy nie zwolnia Nord Stream 2 z prawa unijnego. Dalsze opóźnienie?, https://biznesalert.pl.

Jakóbik, W., PGNiG wygrał z Gazpromem. Rosjanie będa musieli zwrócić ok. 1,5 mld dolarów, https://biznesalert.pl.

Łaskot-Strachota, A., Kardaś, S., Bajczuk, R., Porozumienie w sprawie finansowania Nord Stream 2, Warszawa 2017.

Młynarski, T., Bezpieczeństwo energetyczne w pierwszej dekadzie XXI wieku. Mozaika interesów i Geostrategii, Kraków 2011.

Nord Stream 2 i Ukraina: Bitwa o tranzyt, https://www.energetyka24.com.

Paszkiewicz, E., Bezpieczeństwo energetyczne Unii Europejskiej w sektorze gazu ziemnego, „Przegląd Geopolityczny” 2018, nr 23.

Pronińska, K. M., Bezpieczeństwo energetyczne w stosunkach UE - Rosja, „Geopolityka i Ekonomia Surowców Energetycznych” 2012. 
Ruszel, M., Wpływ rosyjsko-ukraińskich kryzysów gazowych na politykę energetyczną UE - ujęcie teoretyczne, Rzeszów 2015.

Sad UE odrzucit skargi Nord Streamu dyrektywe gazowa, https://www.gazetaprawna.pl/.

Strzałkowski, M., Szwajcarska spółka zawiesza budowę Nord Stream 2, https:// www.euractiv.pl/.

Szeptycki, A., Relations between Russia and Ukraine in the gas sector, [in:] Geopolitics of pipelines. Energy interdependance and inter - state relations in the pst soviet area, ed. E. Wyciszkiewicz, Warsaw 2009.

Turowski, P., Bezpieczeństwo energetyczne na szczycie NATO $w$ Warszawie: priorytetem dywersyfikacja dostaw ropy i gazu, [in:] Bezpieczeństwo energetyczne. Koncepcje, wyzwania, interesy, eds. J. Gryz, A. Podraza, M. Ruszel, Warszawa 2018.

Wojcieszak, Ł., Polska, Ukraina i Białoruś wobec problemu dostaw i tranzytu rosyjskiego gazu, Bielsko-Biała 2013.

Wróbel, A., Turecki Potok-gazociąg, którym rosyjski gaz trafi na południe Europy, https://www.portalmorski.pl.

Zaniewicz, M., Ukraina może przetrwać ponad rok bez importu gazu. Czy później kupi go od Polski?, https://www.energetyka24.com.

Jakub Siotor - mgr stosunków międzynarodowych, doktorant w Zakładzie Międzynarodowych Stosunków Gospodarczych i Integracji Europejskiej w Instytucie Studiów Międzynarodowych Uniwersytetu Wrocławskiego.

ORCID: 0000-0002-3554-429X 